(REVIEW ARTICLE)

\title{
Relationships between probiotic lectins and postbiotics
}

\author{
Lakhtin Vladimir *, Lakhtin Mikhail, Davydkin Valeriy, Melikhova Alexandra and Davydkin Igor \\ Department of Medical Biotechnology, G.N. Gabrichevsky Research Institute for Epidemiology and Microbiology, Russia \\ 125212, Moscow, Admiral Makarov Street, 10.
}

Publication history: Received on 26 June 2020; revised on 14 July 2020; accepted on 15 July 2020

Article DOI: https://doi.org/10.30574/wjarr.2020.7.1.0234

\begin{abstract}
The ways within metabolic axes (from intestine biotopes to another body types of biotopes) and experimental approaches in study of postbiotics in connection to probiotic lectin system functioning are proposed, described and discussed. The own data on functioning of the mucosal biotope probiotic compartment (probiotic cells plus probiotic lectins) serve the basis to systematize, detail, and simplify the search, characterization, and application of postbiotics of potential therapeutic significance. Probiotic lectin system shows itself as an important source and regulator of postbiotic system recognizing glycoconjugates needed for a deeper mucosal immunity. Probiotic lectins possess potential of the direct and indirect conversion into synergistic sets of postbiotics. Consideration of relationships between probiotic lectins and postbiotics is important for increasing microbiocenose health support, makes reliable event forecasting, and justifies further algorithms of recognition processes in connection with prognostic mucosal immunity.
\end{abstract}

Keywords: Probiotics; Postbiotics; Probiotic lectins; Glycoconjugates; Health; Diseases.

\section{Introduction}

Postbiotics (PB) include metabolites of the vital functioning probiotics, early or late products of the probiotic cell surface envelope and cell wall molecules and their complexes resulting in a broad spectrum of useful for human activities which normalize, stimulate and support processes directed against infections, tumors and other pathologies when function in mucosal biotopes, tracts and organs. PB are represented as products of bacterial cell wall hydrolysis (peptidoglycans and lipopolysaccharides), cell surface or secreted proteins and polysaccharides, derivatives of amino acids (Trp and others) and short-chain fatty acids, vitamins which participate in supporting healthy status of organism (preferentially mucosal open cavities) [1,2]. Therapeutic PB (TPB) are factors supporting health and directing against infectious processes and diseases [2-9]. Objects of PB therapy include pathological cases and diseases of children and adults that accompany alterations of mucous (enterocolitis, diarrhea [also of rotavirus nature], pharyngitis, laryngitis), antibiotic resistant infections, Non-Alcoholic Fatty Liver Disease (NAFLD), neurologic pathologies, others [3].

It was shown by us that probiotic lectin systems (PLS recognizing and reversibly binding carbohydrates and glycoconjugates [GC] but are different from antibodies and true enzymes) are new perspective factors of immunity support. They are widely distributed in the human body, participate in innate immunity and co-function with other ptotective systems. PLS serve the supra-molecular basis for assembling effectors, involve in forming healthy dynamic reversible infrastructure and signaling network, and are directed against pathologies; they operate within the framework of organism lectin super-system with probiotic action and results [10-14].

According to both own and literature data, relationships between cell surface (glyco) proteins-containing recognition structures of lectin type are now obvious. The latter is also confirmed in case of the whole probiotic compartment in biotope (PLS and probiotic cells) in reactions influencing functional status of the mucosal epithelial barrier - advanced post of the mucosal immunity at the level of mucosal organs [15-19]. PLS participate in infrastructure organization and

\footnotetext{
* Corresponding author: Lakhtin Vladimir
}

Copyright (C) 2020 Author(s) retain the copyright of this article. This article is published under the terms of the Creative Commons Attribution Liscense 4.0. 
signaling within mucosal biotope; they function as metabolomebiotics and carriers of metabiotic drugs of GC type, protect mucous, contribute to contraction diseases of microbiocenoses, reveal similar to cytokines functions of supporting healthy biotope status [20-23]. The aim - to propose theoretical justification and experimental approaches for study of TPB in direction of pathological targets as it takes place in cases of interaction between PLS and GC; to evaluate contribution and prospects of TPB as additional factor of mucosal immunity.

\section{Pathway relationships between PLS and PB}

\subsection{Pathways of probiotic lectins convertion to PB [24-33]}

Possible mechanism of such conversion includes shedding cell surface associated PLS into liquid surrounding. Further early and delayed transformation and degradation of secreted proteins and their complexes into more widely repertoire of GC-recognizing components with lower molecular masses and increased traffic, permeability and availability to targets took place and indicated more pronounced adaptive molecular potential of PB. We established the strain-specific protease systems (proteinases plus peptidases) functioning in multistrain probiotic microbiocenosis (Acilact) as well as (probiotic bifidobacterial strain)-depended depolymerases. These hydrolases play an important role in conversion and truncating/limiting hydrolysis of the original products. Using visual imagination in a real time, on example of bifidobacterial cultures we showed that depolymerases are localized within contact region between substrates cationic exopolysaccharides (EPS) and enzyme forms (possessing lower pI compared to EPS), and process of hydrolysis (as parallel one to PB accumulation) is revealed and increased in the late and long-stored probiotic cultures. Another possible mechanism of the peptide PB effectors involves interaction of effectors with probiotic bacterial biosurfactants (BS) [26].

\subsection{Pathways of co-functioning and synergism of PLC and other type effectors and factors [25-28, 34, 35]}

Such pathways include co-functioning PLS and BS or EPS of the probiotic strains of bifidobacteria and lactobacilli. Delivery of PLS and/or GC (those who enter into synergetic functioning not only among themselves but also with other categories of anti-pathogens such as antibiotics, chemotherapeutic agents, other drugs) as well as PLS-GC complexes (complexes with a new extended recognition potential and biological activities) to the mucosal biotopes are improved.

\subsection{Other factors increasing PB levels}

\subsubsection{Cultural peptide formulas for evaluation of $P B$}

On example of Acilact system, peptide formulas were proposed using estimation of partially hydrolyzed protein in culture, $[36,37]$. It is possible to use proposed approaches and peptide formulas in study of potential PB sets, kits and their combinations.

\subsubsection{Sources of the Trp catabolism derived $P B$}

On example of cultural purified proteins and PLS of bifidobacterial probiotics and Acilact, the simple sensitive analysis of the Trp and its derivatives presence (using second derivative of absorbance protein spectra or fluorescent spectra) can be performed $[36,38]$. The strain-dependence of absolute quantitatives of Trp and other key amino acids which are producing by lactobacilli of Acilact has been established [36]. Effective delivery systems can be developed on Trp derivative based delivery of PB into mucous [39].

\subsubsection{Controlled degradation of the probiotic polymers with hydrolases}

According to visual chemiluminescent image-analysis in a live regime, the following data allowing biopolymer degradation control were obtained: a) visible changes of the protein patterns due to the action of (multi)straindependent presence of proteinase systems in (multi)probiotic cultures were established (on example of Acilact); b) depolymerases are localized in contacts to their targets (EPS) as in cases of probiotic bifidobacterial cultures (the visible destruction within the border of well-visible contact region as the local alteration of the symmetry of EPS image pattern is observed); c) hydrolysis of initial biopolymers can be simply controlled and visually described according to formula proposed by us (on example of bifidobacteria) [25, 40,41]. The use of PLS as a regulating factor in respect of hydrolases in biotope-like surroundings is promising for modulation [inhibition] of activities up to 60-100\%) as in case of using eukaryotic enzymes [42]. The promise of the latter aspect of PLS is confirmed by numerous data on the role of lectins as enzyme modulators and stabilizers (through enzyme carbohydrate moiety) for all enzyme classes [27-31]. 


\subsubsection{Dispersion of a cell mass to enhance microbial metabolism [43-45]}

During cultivation of bifidobacteria and lactobacilli when cultures reach a certain concentration of cells with properties of agglutinins (such as cell surface EPS, glycoprotein complexes and PLS) in culture, conglomerates of microorganisms with a property of mini-biofilm conservation are formed. For destruction of the intercellular matrix and resulting increase of release of free colony-forming cells, a method of dispersion (minutes) of culture liquid can be proposed (on example of bifidobacteria B. adolescentis MC-42, B. longum and B. bifidum 791) using ferromagnetic elements of an electromagnetic dispersant [43]. It is shown that an effectiveness of the method depends on both a microbiocenosis species composition and the choice of nutrient type (on examples of casein-yeast and thioglycol culture media). This method allows increasing the number of colony forming cells of bifidobacteria in suspension up to 20 times. High cell concentrations in mixed bifidobacteria-lactobacilli microbiocenoses having cell associates may be considered as a further perspective proposal for formulas of microbiocenosis delivery into mucous of organism open cavities to increase stability and survival of multiprobiotics producing PB.

\subsection{Ways to evaluate the microbial associates influence [43-47]}

Bifidobacterial and lactobacillar cell associates were observed as processes accompanying isolation and storing of microbiocenosis preparations as well as in connection with accumulation of the cultural microbial masses. Effective agents of the cell aggregates dissociation can involve not only combinations of hydrolases, but also BS, EPS, detergents and chelators of metal cations (agents are present in cultures or added to them). Optical density registration of microbial suspensions within first three days cultures in the presence of PL allows tracking and separating processes of cell dissociation and amplification. In case of solid-phased microbiocenoses, there are perspective approaches to visual control of dissociation of PLS-sensitized cells within assembled cell gradients imitating biofilms [47].

\subsection{Strategies and algorithms in study of TPB recognizing GC $[14,24,36,48-50]$}

They include the following ones (in brackets - some details):

- *the choice of metabolic axis "intestine-skin/ liver/ brain/ other" for the preferential PB action [3];

- *the choice of microbiocenosis/ microbiome cultures (accenting the role of taxonomic status of composition; the choice of the nutrient media with specific stimulators within microecological network metabolism);

- *evaluation/ monitoring of amino acids, volatile fatty acids, cell wall constituents, other perspective established chemical structures and compositions as well as bio-oligo- and polymers to ensure probiotic pressure and obtaining predicted sets of TPB;

- *further optimization of targeting cell cultures (the use of optimized physical and physico-chemical and chemical stimules and additives) when wishful producers of TPB must reveal a limited but increased profile of action;

- *identification of and sorting PLS (as potential carriers of GC of therapeutic significance) upon screening of multi/mono-probiotic cultures;

- *the choice and optimized conversion procedures PLS-to-PB (using separate or mixed [as in multi-strain probiotics] hydrolases, BS, EPS, detergents, cationic metals, other ingredients/ stimulators needed);

- *identification of leaders in co-existing competitive populations of microorganisms (leader isolates/strains of microbes that can reorganize niche relationships between microbial (sub)species in a considered microbiocenosis [50] to accent production of PB needed;

- *testing targeted TPB (interaction with sets of selected critical GC involving in TBB based reactions of the local [according to the axis "intestinal-another body part"] physiological significance).

\section{Conclusion}

The prospects of obtaining and study of PB directing against GC-containing targets are indicated. The data presented systematize, detail, and simplify search, characterization, and application of TPB in accompanying therapy. PLS are perspective sources and regulators of production of synergistic sets of TPB. The prospects of forming and designing TPB of lectin recognition type directed against the emergence and development of a wide range of infectious processes and related diseases in the body are open and will be extended. 


\section{Compliance with ethical standards}

\section{Acknowledgments}

The authors are grateful to the heads of the laboratories of the department of Medical Biotechnology of G.N. Gabrichevsky Research Institute for Epidemiology and Microbiology for making available their facilities for usage and support. Special thanks are expanded to those who contributed to the research and writing of this article.

\section{Disclosure of conflict of interest}

Authors declare the absence of conflict of interest statement.

\section{References}

[1] Patil S, Sawant S, Hauff K and Hampp G. (2019). Validated Postbiotic Screening Confirms Presence of Physiologically-Active Metabolites, Such as Short-Chain Fatty Acids, Amino Acids and Vitamins in Hylak Forte. Probiotics and Antimicrobial Proteins, 11(4), 1124-1131.

[2] Paul D, Manna S and Mandal SM. (2018). Antibiotics Associated Disorders and Postbiotics Induced Rescue in Gut Health. Current Pharmaceutical Design, 24(7), 821-829.

[3] Lakhtin MV, Lakhtin VM, Davydkin VY, Melikhova AV, Davydkin IY and Aleshkin VA. (2020). Postbiotics Against Infections, Diseases and Other Pathologies. Problems of Scientific Thought (Dnepr, Ukraine) [Problemy nauchnoy misli (Dnepr)], 3(7), 3-21.

[4] Afanasiev SS, Aleshkin VA, Lakhtin VM, Nesvizhsky YV, Galimzyanov KM, Karaulov AV, Aleshkin AV, Rubalsky OV, Bogdanova EA, Lakhtin MV, Afanasiev DS, Afanasiev MS, Rubalskaya EE, Rubalsky MO and Nesvizhskaya MY. (2014). Composition containing the waste products of bacteria which are useful for human organism. Patent RU $2535152(13)$ C1.

[5] Wong AC and Levy M. (2019). New Approaches to Microbiome-Based Therapies. mSystems, 4, 4(3).

[6] Malagón-Rojas JN, Mantziari A, Salminen S and Szajewska H. (2020). Postbiotics for Preventing and Treating Common Infectious Diseases in Children: A Systematic Review. Nutrients, 31, 12(2).

[7] Ji Y, Yin Y, Li Z and Zhang W. (2019). Gut Microbiota-Derived Components and Metabolites in the Progression of Non-Alcoholic Fatty Liver Disease (NAFLD). Nutrients, 25, 11(8).

[8] Maguire M and Maguire G. (2019). Gut dysbiosis, leaky gut, and intestinal epithelial proliferation in neurological disorders: towards the development of a new therapeutic using amino acids, prebiotics, probiotics, and postbiotics. Reviews in the Neurosciences, 30(2), 179-201.

[9] Rigo-Adrover MDM, Knipping K, Garssen J, van Limpt K, Knol J, Franch À, Castell M, Rodríguez-Lagunas MJ and Pérez-Cano FJ. (2019). Prevention of Rotavirus Diarrhea in Suckling Rats by a Specific Fermented Milk Concentrate with Prebiotic Mixture. Nutrients, 18, 11(1).

[10] Lakhtin MV, Lakhtin VM, Afanasiev SS, Aleshkin VA and Mironov AYu. (2018). Lectins and Glycoconjugates in Presentation of Antigens and Protection Against Pathogens. The review of Literature. Russian Clinical Laboratory Diagnostics [Klinicheskaya Laboratornaya Diagnostika (Moskva)], 63(10), 619-625.

[11] Lakhtin MV, Lakhtin VM, Aleshkin VA and Afanasiev SS. (2019). Lectin-dependent Diversity of Natural Killer Populations and Communications Against Tumors and Viruses. Medical Immunology (Saint Petersburg) [Meditsinskaya immunologiya (Sankt Peterburg)], 21(4), 595-602.

[12] Lakhtin MV, Lakhtin VM, Mironov AY, Aleshkin VA and Afanasiev SS. (2020). Human Lectin Supersystems with Probiotic and Protective Action. Russian Clinical Laboratory Diagnostics [Klinicheskaya Laboratornaya Diagnostika (Moskva)], 65(4), 231-238.

[13] Lakhtin M, Lakhtin V, Aleshkin A, Bajrakova A, Afanasiev S and Aleshkin V. (2012). Lectin Systems Imitating Probiotics: Potential for Biotechnology and Medical Microbiology // In: "Probiotics 2012", E.C. Rigobelo (Ed.). New York, InTech, 417-432.

[14] Lakhtin MV, Lakhtin VM, Afanasiev SS, Aleshkin VA, Afanasiev MS and Korsun VF. (2014). Lectins and their Systems: Detection, Visualization and Co-functioning (Results, Approaches and Conceptions). The Overview of Own Works // Materiály X mezinárodní vědecko - praktická conference «Věda a technologie: krok do 
budoucnosti - 2014». - Vol. 26. - P. 47-55. Biologické vědy.: Praha. Publishing House «Education and Science» s.r.o. ISBN 978-966-8736-05-6.

[15] Gao J, Li Y, Wan Y, Hu T, Liu L, Yang S, Gong Z, Zeng Q, Wei Y, Yang W, Zeng Z, He X, Huang SH and Cao H. (2019). A Novel Postbiotic From Lactobacillus rhamnosus GG With a Beneficial Effect on Intestinal Barrier Function. Frontiers in Microbiology, 10, 477.

[16] Liu Q, Yu Z, Tian F, Zhao J, Zhang H, Zhai Q and Chen W. (2020). Surface components and metabolites of probiotics for regulation of intestinal epithelial barrier. Microbial Cell Factories, 19(1), 23.

[17] Lakhtin MV, Lakhtin VM and Aleshkin VA. (2020). The Role and Prospects of Lectins of Indigenous Mucosal Microflora in Regulation of Mucosal Microbiocenoses of Open Cavities of the Body. Problems of Scientific Thought (Dnepr, Ukraine) [Problemy nauchnoy misli (Dnepr)], 4 (2), 9-41.

[18] Lakhtin MV, Lakhtin VM and Aleshkin VA. (2020). The Role of Lectins of Microbes of Indigenic Mucus Microflora in Regulation of Mucosal Microbiocenoses of the Organism Open Cavities and Immuno-biological Supervision. Ural Scientific Bulletin (Uralsk, Kazakhstan) [Uralskiy nauchniy vestnik (Uralsk, Kazahstan)], 4(2), 9-41.

[19] Lakhtin MV, Lakhtin VM, Afanasiev SS and Aleshkin VA. (2016). Mucosal Open Cavities as the Organ of Increased Resistance and Effectiveness. Journal of Advances in Biology and Biotechnology, 10(3), 1-10.

[20] Lakhtin MV, Lakhtin VM, Afanasiev SS and Aleshkin VA. (2016). Applied Prospects of Probiotic Lectin Systems of the Human Symbiotic Microbiocenosis Strains and Consortia // Applied and Fundamental Studies : Proceedings of the 10th International Academic Conference. November 21-22, 2016, St. Louis, Missuri, USA. Science and Innovation Center Publishing House, Ltd, 5-15.

[21] Lakhtin MV, Lakhtin VM, Afanasiev SS and Aleshkin VA. (2017). Lectins of Probiotics Against Diseases of Microbiocenoses in Human Organism. Ural Scientific Bulletin (Uralsk, Kazakhstan) [Uralskiy nauchniy vestnik (Uralsk, Kazahstan)], 2(9), 35-45.

[22] Lakhtin MV, Lakhtin VM, Bajrakova AL, Davydkin VY, Davydkin IY, Afanasiev MS, Afanasiev SS and Aleshkin VA. (2020). Probiotic Recognition Factors Influencing Microbiocenosis Microecology: Prospects for Medical Biotechnology. Pridneprovskiy Scientific Bulletin [Pridneprovsky nauchny vestnik (Dnepropetrovsk)], 3(4), 319.

[23] Lakhtin VM Lakhtin MV, Afanasiev SS and Aleshkin VA. (2016). Symbiotic Lectins - Metabolomebiotics and Carriers of Metabiotics. Gastroenterology of Saint Petersburg [Gastroenterologiya Sankt-Peterburga], 3-4.

[24] Lakhtin MV, Lakhtin VM, Afanasiev SS and Aleshkin VA. (2015). Diversity of Lectin Systems of Probiotic Bacteria. Bulletin of Eastern-Siberian Scientific Center (Acta biomedical scientifica), 5, 79-82.

[25] Lakhtin MV, Afanasiev SS, Lakhtin VM, Aleshkin VA, Karaulov AV, Teply DL, Nesvizhsky YV, Voropaeva EA, Afanasiev MS, Aleshkin AV and Rubalskaya EE. (2014). Structure-Function Associates of Exopolymers of Probiotic Bifidobacteria and Lactobacilli. Natural Sciences (Astrakhan) [Yestestvennye nauki (Astrahan)], 3(48), 66-75.

[26] Lakhtin MV, Lakhtin VM and Aleshkin VA. (2019). Image Fluorescent Analysis of Electrophoretically Separated Sssociated Exopolymers in Two-Dimensional Phenotyping Gram Positive Bacteria. Ural Scientific Bulletin (Uralsk, Kazakhstan) [Uralskiy nauchniy vestnik (Uralsk, Kazahstan)], 4(11), 6-18.

[27] Lakhtin MV, Lakhtin VM, Aleshkin VA, Afanasiev SS and Aleshkin AV. (2010). Lectins and Enzymes in Biology and Medicine. Moscow: Dynasty, 496.

[28] Lakhtin V, Lakhtin M and Aleshkin V. (2019). Interaction of Oxydoreductases, Transferases, Lyases, Isomerases and Ligases with Carbohydrate Sensitive Reagents. Problems of Scientific Thought (Dnepr, Ukraine) [Problemy nauchnoy misli (Dnepr)], 5(8), 3-66.

[29] Lakhtin V, Lakhtin M and Aleshkin V. (2019). Interaction of esterases with carbohydrate-sensitive reagents. News of Science and Education, 4(8), 3-80.

[30] Lakhtin V, Lakhtin M and Aleshkin V. (2019). Interaction of Glycosidases with Carbohydrate-Sensitive Reagents. News of Science and Education, 5(8), 3-93.

[31] Lakhtin V, Lakhtin M and Aleshkin V. (2019). Interaction of Proteases and Other Hydrolases (EC 3.5 and Higher) with Carbohydrate-Sensitive Reagents. News of Science and Education, 6(8), 3-86.

[32] Lakhtin VM, Lakhtin MV, Afanasiev SS and Aleshkin VA. (2017). Probiotic Lectin Systems Potential: The glycoconjugate binding strategies. Madrige Journal of Food Technology, 2(1), 69. 
[33] Lakhtin MV, Lakhtin VM and Afanasiev SS. (2015). Acilact - Multistrain Antagonistic System of Degradation and Synergism // Materiały XI Międzynarodowej naukowi-praktycznej konferencji, 9, 66-69.

[34] Lakhtin M, Lakhtin V, Afanasiev S, Bajrakova A and Aleshkin V. (2017). Probiotic Lectins: Microbiocenosis Functional Organizers // In Abstract Book: Environmental Microbiology/Microbial Ecology /Microbial Communities - Part II, Abstract FEMS7-1754. [7th FEMS 2017 (9-13 July, 2017, Valencia, Spain). PV14 Poster Viewing. Session Environmental Microbiology/Microbial Ecology /Microbial Communities - Part II. Abstract 604].

[35] Lakhtin V, Lakhtin M and Aleshkin V. (2017). Synbiotic Mini-bioreactor Regulating by Probiotic Lectins, Metal Cations and Glycoconjugates // In: Proceedings of the 19th Eurocarb (2-6 July 2017, Barcelona). Scientific program \& Abstract book, 591.

[36] Lakhtin MV, Lakhtin VM, Aleshkin VA and Afanasiev SS. (2019). Metabolite Multiprobiotic Formulas for Microbial Health // In: "Oral Health by Using Probiotic Products", Razzagh Mahmoudi (Ed.). 2019. London, United Kingdom: InTech, 71-91.

[37] Lakhtin MV, Afanasiev SS, Lakhtin VM, Aleshkin VA and Afanasiev MS. (2014). Peptide Formulas of Cultural Fluids of Multi-strain Consortium and Its Ingredient Strains of Gram Positive Bacteria // Materiały X Międzynarodowej naukowi-praktycznej konferencji «Strategiczne pytania światowej nauki». Volume 28, 26-30. Nauk biologicznych. : Przemyśl. Nauka i studia.

[38] Lakhtin MV, Shubin VV, Lakhtin VM and Afanasiev SS. (2014). Optical Properties of Lectins in Solutions: Prerequisites for Bio-Recognition // At the intersection of science. Physical and Chemical Series [Text]: II International scientific Internet-conference : Materials of the conference (Kazan, 28 January 2014) In 2 volumes / Service of virtual conferences Pax Grid. - Kazan : Individual businessman Sinyaev Dmitry Nikolayevich, 2.

[39] Puccetti M, Giovagnoli S, Zelante T, Romani L and Ricci M. (2018). Development of Novel Indole-3-AldehydeLoaded Gastro-Resistant Spray-Dried Microparticles for Postbiotic Small Intestine Local Delivery. Journal of Pharmaceutical Sciences,107(9), 2341-2353.

[40] Lakhtin MV, Lakhtin VM, Aleshkin AV, Afanasiev SS and Aleshkin VA. (2013). Highly Sensitive Revealing System Proteases in Cultural Fluids of Gram Positive Bacteria Representing Multi-strain Consortium // Actual problems of biochemistry and bionanotehnologies : IV International scientific Internet-conference : Materials of the conference (Kazan, 16-17 October, 2013) : 2 volumes / Service of virtual conferences Pax Grid ; Kazan : Individual businessman Sinyaev Dmitry Nikolayevich, 2013. Volume 1 [compiler D.N. Sinyaev]: 167-172.

[41] Lakhtin MV, Lakhtin VM, Davydkin VY, Afanasiev SS and Aleshkin VA. (2019). Image monitoring evaluation of biohydrolysis in cultures of Gram positive bacteria. News of Science and Education, 5(11), 13-20.

[42] Lakhtin MV, Kozlov LV, Lakhtin VM, Aleshkin VA, Afanasiev SS, Karaulov AV, Nesvizhsky YuV, Bayrakova AL, Voropaeva EA, Afanasiev MS, Bichucher AM, Panurina RL and Rubalsky EO. (2012). Protection of Potential Human Antibodies Against Proteolysis with Secrets of Candida clinical Strains in the Presence of Lectins of Human Probiotic Bacteria. Astrakhan Medical Journal [Astrahansky meditsinsky zhurnal], 7(1), 63-68.

[43] Kaminsky VV, Davydkin VY, Davydkin IY, Melikhova AV and Lakhtin VM. (2019). Increasing of the Concentration of Bifidobacterial Cells in Bio-suspension after Grawing // VI International conference of young scientists. 2019: Book of Abstracts. — Novosibirsk : Novosibirsk National Research State University, 89-92.

[44] Taverniti V, Koirala R, Dalla Via A, Gargari G, Leonardis E, Arioli S and Guglielmetti S. (2019). Effect of Cell Concentration on the Persistence in the Human Intestine of Four Probiotic Strains Administered through a Multispecies Formulation. Nutrients, 11(2).

[45] Forssten S and Ouwehand AC. (2020). Dose-Response Recovery of Probiotic Strains in Simulated GastroIntestinal Passage. Microorganisms, 8(1).

[46] Lakhtin MV, Aleshkin VA, Lakhtin VM, Afanasiev SS, Karaulov AV, Galimzyanov KL, Nesvizhsky YuV, Bayrakova AL, Voropaeva EA, Aleshkin AV and Rubalsky EO. (2011). Behavior of Candida tropicalis and Candida krusei in the Presence of Probiotic Lectins. Astrakhan Medical Journal [Astrahansky meditsinsky zhurnal], 6(3), 97-101.

[47] Lakhtin VM, Lakhtin MV, Korsun VF and Shenderov BA. (2008). Combined Potential of Lectins of Probiotic Microorganisms and Fungi in Conditions of Organization and Function of the Model Eukaryotic Cell Biofilms - for Further Application in Clinical Practice Using Phytocompositions. Practical Phytotherapy (Moscow) [Prakticheskaya fitoterapiya (Moskva)], 2, 11-17. 
[48] Lakhtin MV, Lakhtin VM, Aleshkin VA and Afanasiev SS. (2020). The Recognizing Glycoconjugates Proteins of the Human Mucosal Immunity: Lectin Systems of Probiotic Compartment of Mucosal Biotopes of Open Cavities of Organism. Pharmacy (Saint Petersburg) [Farmatsiya (Sankt Peterburg)], 69 (1), 10-16.

[49] Lakhtin MV, Lakhtin VM, Afanasiev SS, Bajrakova AL, Afanasiev MS and Aleshkin VA. (2019). Mucosal Candida Species Microecology, Sensitivity to Antifungals, Antifungal Strategies Considering Probiotic Pressure. News of Science and Education, 5(3), 3-21.

[50] Lakhtin MV, Lakhtin VM, Afanasiev SS, Bajrakova AL and Aleshkin VA. (2016). Leader and Consortia Microorganisms in Human Synbiotope Balanced Microbiocenosis // Materiały XII Międzynarodowej naukowipraktycznej konferencji «Naukowa przestrzeń Europy - 2016» Volume 10. Medycyna. Nauk biologicznych.: Przemyśl. Nauka i Studia - Str. 68-75.

\section{How to cite this article}

Lakhtin V, Lakhtin M, Davydkin V, Melikhova A and Davydkin I. (2020). Relationships between probiotic lectins and postbiotics. World Journal of Advanced Research and Reviews, 7(1), 142-148. 